\title{
ANALISIS PERENCANAAN DAN REALISASI ANGGARAN PENDAPATAN DAN BELANJA PADA KANTOR BADAN PENGELOLA KEUANGAN DAERAH (BPKD) PROV. SUL-SEL TAHUN 2016-2017
}

\author{
Lilly Ibrahim \\ lillyibrahim@unismuh.ac.id \\ Fakultas Ekonomi dan Bisnis \\ Universitas Muhammadiyah Makassar \\ Muh Nur Abdi \\ muhnurabdi@unismuh.ac.id \\ Fakultas Ekonomi dan Bisnis \\ Universitas Muhammadiyah Makassar \\ Elyang \\ elvanivan@gmail.com \\ Fakultas Ekonomi dan Bisnis \\ Universitas Muhammadiyah Makassar
}

\begin{abstract}
This study aims to determine whether the practice of Islamic Corvorate Social Responsibility affects the This study aims to determine the budget planning with the effectiveness and efficiency of the realization of the revenue and expenditure budget in the Badan Pengelola Keungan Daerah (BPKD) of South Sulawesi Province 2016 to 2017. The type of research used is descriptive research with a quantitative approach. The data processed is a summary of the Budget Work Plan and Budget Realization at the Badan Pengelola Keungan Daerah (BPKD) from 2016 to 2017 obtained from the annual report of the regional financial management body. The calculation technique used in the study is calculating the effectiveness ratio and efficiency ratio of Badan Pengelola Keungan Daerah budget realization. While the data analysis technique used in the study was to calculate the effectiveness and efficiency of the realization of the Badan Pengelola Keungan Daerah budget through the results of the overall income and expenditure budget. Based on the results of calculations and data collection on budget planning Badan Pengelola Keungan Daerah managed to prepare and plan its budget well until the realization stage, but the realization of the budget has been running quite effectively but less efficiently in 2016 to 2017, which is due to spending greater than income.
\end{abstract}

Key words : Planning and Budget Realization

\begin{abstract}
Abstrak
Penelitian ini Penelitian ini bertujuan untuk mengetahui perencanaan anggaran dengan efektiftas dan efisiensi realisasi anggaran pendapatan dan belanja pada Badan Pengelola Keuangan Daerah (BPKD) Provinsi Sulawesi Selatan tahun 2016 sampai dengan 2017. Jenis penelitian yang digunakan adalah peneltian deskriptif dengan pendekatan kuantitatif. Data yang diolah adalah ringkasan Rencana Kerja Anggaran dan Realisasi Anggaran pada badan pengelola keuangan daerah (BPKD) tahun 2016 sampai 2017 yang didapatkan dari laporan tahunan badan pengelola keungan daerah. Teknik perhitungan yang digunakan dalam penelitian adalah menghitung rasio efektifitas dan rasio efisiensi realisasi anggaran badan pengelola keungan daerah. Sedangkan Teknik analisis data yang digunakan dalam penelitian adalah dengan menghitung efektifitas dan efisiensi realisasi anggaran badan pengelola keuangan daerah melalui hasil keseluruhan anggaran pendapatan dan belanja. Berdasarkan hasil perhitungan dan pengumpulan data perencanaan anggaran badan pengelola keuangan daerah berhasil menyusun dan merencanakan anggarannya dengan baik sampai tahap terealisasi, namun realisasi anggaran tersebut telah berjalan cukup efektif akan tetapi kurang efisien di tahun 2016 sampai dengan 2017 , yang dikarenakan pengeluarannya lebih besar daripada pendapatannya.
\end{abstract}

Kata Kunci: perencanaan dan realisasi anggaran 


\section{PENDAHULUAN}

Dalam konteks anggaran organisasi sektor publik, anggaran mencakup rencana-rencana tentang berapa biaya atas rencana yang dibuat dan seberapa besar cara memperoleh uang untuk mendanai rencana tersebut. Laporan keuangan menjadi produk akhir dari suatu proses akuntansi yang bertujuan menyajikan informasi yang menyangkut posisi keuangan bagi sejumlah pemakai dalam pengambilan keputusan, baik bagi pihak Internal maupun Eksternal. Laporan Keuangan ini dimaksudkan agar Laporan Realisasi Anggaran memberikan Informasi Realisasi serta anggarannya.

Menghadapi tekanan untuk efesien harus mampu memperhitungkan biaya ekonomi dan biaya sosial, serta dampak negatif atas aktivitas yang dilakukan. Setiap organisasi pemerintahan pasti menginginkan tujuannya tercapai secara efektif serta efesien dalam merealisasikan anggaran pendapatan dan belanja daerahnya (APBD), terlebih lagi dalam situasi globalisasi seperti masa sekarang ini, untuk itu pemerintah harus menyusun laporan realisasi anggaran sesuai dengan ketentuan yang berlaku.

Permendagri No. 56 Tahun 2007 mendefinisikan bahwa keuangan daerah adalah semua hak dan kewajiban daerah dalam rangka penyelenggaraan pemerintahan daerah yang dapat dinilai dengan uang, termasuk didalamnya segala bentuk kekayaan yang berhubungan dengan hak dan kewajiban daerah tersebut, dalam Kerangka Anggaran Pendapatan Dan Belanja Daerah. Salah satunya Laporan Realisasi Anggaran yang merupakan bagian yang sangat penting dalam suatu perusahaan/instansi, dimana fungsinya untuk mengetahui keadaan keuangan suatu perusahaan/ instansi. Manajemen suatu organisasi, baik yang berorientasi laba maupun non laba, akan selalu dihadapkan pada pengambilan keputusan untuk masa mendatang. Baik buruknya keputusan yang diambil tergantung dari informasi yang digunakan untuk kemampuan manajemen dalam menganlisis serta menginterpretasikan. Salah satu sumber informasi penting yang digunakan manajemen dalam pengambilan keputusan tersebut, terutama keputusan keuangan adalah laporan keuangan. Pendapatan Dan Belanja Daerah. Salah satunya Laporan Realisasi Anggaran yang merupakan bagian yang sangat penting dalam suatu perusahaan/instansi, dimana fungsinya untuk mengetahui keadaan keuangan suatu perusahaan/ instansi.

Manajemen suatu organisasi, baik yang berorientasi laba maupun non laba, akan selalu dihadapkan pada pengambilan keputusan untuk masa mendatang. Baik buruknya keputusan yang diambil tergantung dari informasi yang digunakan untuk kemampuan manajemen dalam menganlisis serta menginterpretasikan. Salah satu sumber informasi penting yang digunakan manajemen dalam pengambilan keputusan tersebut, terutama keputusan keuangan adalah laporan keuangan.

Laporan keuangan yang menyajikan informasi sangat dibutuhkan berbagai pihak seperti pemerintah daerah sebagai aparat yang dipercaya oleh masyarakat dalam mengelola keuangan negara dan rakyat yang menjadi pemegang kekuasaan tertinggi dalam mengelola keuangan negara dan rakyat yang menjadi pemegang kekuasaan tertinggi dalam memberikan kepercayaan kepada pemerintah dalam mengelola keungan dengan sebaikbaiknya guna mencapai Good Government 
Governance, dicerminkan dengan adanya akuntabilitas dan transparansi pelaporan keuangan. Perencanaan menjadi faktor yang mempengaruhi Realisasi anggaran karena masih adanya anggapan bahwa tidak semua anggaran yang diusulkan akan disetujui, sehingga anggaran yang diusulkan lebih besar dari yang dibutuhkan tanpa memperhatikan kebutuhan riil di lapangan dan kemudahan dalam implementasinya. Pada dasarnya Anggaran sebagai alat perencanaan mengindikasikan target yang harus dicapai oleh pemerintah dalam melaporkan semua kegiatan keuangannya. Laporan itu berguna untuk mengetahui seberapa besar realisasi terhadap anggaran APBN yang telah ditetapkan sebelumnya.

Anggaran merupakan elemen sistem pengendalian manajemen yang berfungsi sebagai alat perencanaan dan pengendalian agar manajer dapat melaksanakan kegiatan organisasi secara lebih efektif serta efisien. Anggaran pada sektor publik terkait dengan proses penentuan jumlah alokasi dana untuk tiap-tiap program dan aktivitas dalam satuan moneter yang menggunakan dana milik rakyat. Hal inilah yang menjadi perbedaan dengan anggaran sektor swasta karena tidak berhubungan dengan pengalokasian dana dari masyarakat. Pada sektor publik pendanaan organisasi berasal dari pajak dan retribusi, laba perusahaan milik daerah atau negara.

Dalam melaksanakan anggaran dan menilai sendiri tentang pencapaian anggaran yang telah di tetapkan maka semakin baik kinerjanya. Anggaran Pendapatan dan Belanja Daerah (APBD) disusun berdasarkan pendekatan kinerja, yaitu suatu sistem anggaran yang mengutamakan upaya pencapaian hasil kerja output dari perencanaan alokasi biaya atau input yang ditetapkan. Anggaran Pendapatan Belanja Daerah (APBD) Tujuannya adalah untuk meningkatkan pelayanan publik dan memajukan perekonomian daerah, serta meningkatkan efisiensi dan efektivitas dalam penyelenggaraan otonomi daerah. Belanja adalah semua pengeluaran dari rekening kas umum Negara/Daerah yang akan mengurangi saldo anggaran lebih dalam periode tahun anggaran yang bersangkutan yang tidak akan diperoleh kembali pembayaran oleh pemerintah. Saat perekonomian sedang lesu dan sektor privat tidak mampu berjalan dengan semestinya, belanja pemerintah digunakan sebagai penggenjot perekonomian secara agregat. Belanja pemerintah tersebut tertuang dalam Anggaran Belanja dan Pendapatan Negara (APBN). Belanja juga merupakan semua pengeluaran dan rekening kas umum Negara/Daerah yang akan mengurangi saldo anggaran lebih dalam periode tahun anggaran yang bersangkutan yang tidak akan diperoleh kembali pembayarannya oleh pemerintah, secara normative. Badan Pengelola Keuangan Daerah (BPKD) merupakan unsur pelaksanaan pemerintah Daerah pada bagian keuangan yang bertugas untuk melakukan penegelola keuangan di daerah Sulawesi selatan.

Berdasarkan uraian latar belakang masalah di atas, maka penulis tertarik untuk melakukan penyusunan laporan Akhir dengan mengambil judul "Analisis Perencanaan Dan Realisasi Anggaran Pendapatan dan Belanja pada Badan Pengelola Keuangan Daerah (BPKD) Prov. Sul - Sel tahun 2016 - 2017". 


\section{TINJAUAN PUSTAKA}

\section{a. Anggaran}

Anggaran (Budgeting) merupakan
alat perencanaan, pengendalian dan alat pengawasan dibidang keuangan yang digunakan oleh perusahaan yang berorientasi pada laba maupun non - laba. Dengan menggunakan anggaran maka perkembangan perusahaan / instansi akan dapat dipelajari dengan teliti dan berkesinambungan Anggaran dapat berjalan dengan baik apabila dalam organisasi perusahaan / instansi tersebut ada dukungan aktif, baik dari pelaksanaan tingkat atas maupun tingkat bawah. Hal ini menyangkut kepada manusia, khususnya pada karyawan yang ada pada suatu organisasi dalam melaksanakan kegiatannya. Untuk memahami anggaran, maka pada bab ini akan dibahas mengenai teori yang berhubungan dengan anggaran.

Untuk lebih memahami pengertian anggaran beberapa ahli mengemukakan pendapatnya sebagai contoh Menurut Munandar (2014:1) Anggaran yaitu Suatu rencana yang disusun secara sistematis yang meliputi seluruh kegiatan perusahaan yang dinyatakan dalam unit kesatuan moneter yang berlaku untuk jangka waktu periode tertentu yang akan datang.

\section{b. perencanaan}

Menurut Nugroho dan wrihatnolo (2014) adalah Perencanaan dalam arti luas merupakan upaya manusia meminimalkan ketidakpastian. Perencanaan yang ideal adalah langkah langkah yang dilakukan manusia agar kepastian semakin dekat dalam kehidupan manusia. Perencanaan dalam arti sempit merupakan derivate dari kemampuan foresight yaitu kemampuan mengukur (measuring). Inti dari perencanaan ideal adalah mengukur. Samodra wibawa (2014) perencanaan adalah Proses memilih sekumpulan kegiatan dan memutuskan apa yang harus dilakukan, kapan, bagaimana, dan oleh siapa. Menurut anggarini dan puranto (2016) adalah Perencanaan pada dasarnya merupakan suatu proses untuk menentukan tindakan masa depan yang tepat, melalui urutan pilihan, dengan memperhitungkan sumber daya yang tersedia" Sistem perencanaan pembangunan dalam undang - undang mencakup lima pendekatan dalam seluruh rangkaian perencanaan meliputi;
a. Pendekatan politik
b. Pendekatan teknokratik
c. Pendekatan partisipatif
d. Pendekatan top-down
e. Pendekatan bottom-up

Menurut bhisma. M., et.al (2013), alam membahas aspek perencanaan, ada tiga aspek pokok yang harus diperhatikan. Ketiga aspek yang dimaksud adalah hasil dari pekerjaan perencanaan (outcome planning), perangkat organisassi yang digunakan untuk melakukan pekerjaan perencanaan, serta proses atau langkahlangkah melakukan pekerjaan perencanaan.

Adapun uraian aspek ini adalah sebagai berikut;

1) Hasil dari pekerjaan perencanaan

Hasil dari pekerjaan perencanaan disebut dengan nama rencana yang dapat berbeda antara satu pekerjaan perencanaan dengan pekerjaan perencanaan lainnya.

2) Perangkat perencanaan

Adalah merupakan satuan organisasi yang ditugaskan dan yang bertanggung jawab menyelenggrakan pekerjaan perencanaan.

3) Proses perencanaan 
Adalah langkah - langkah yang harus dilaksanakan pada pekerja perencana.

\section{c. Laporan Realisasi Anggaran}

Menurut Abdul Hafiz Tanjung (2013:71) Laporan Realisasi Anggaran merupakan "ikhtisar sumber, alokasi dan pemakaian sumber daya ekonomi yang dikelola oleh pemerintah pusat/daerah, yang menggambarkan perbandingan antara anggaran dan realisasinya dalam satu periode pelaporan".Secara garis besar, proses penyusunan anggaran terjadi menjadi dua, yakni;

1) Dari atas ke bawah (Top-down)

Merupakan proses penyusunan anggaran tanpa penentuan tujuan sebelumnya dan tidak berlandasakan teori yang jelas. Proses penyusunan anggaran dari atas ke bawah ini secara garis besar berupa pemberian sejumlah uang dari pihak atasan kepada para karyawannya agar menggunakan uang yang diberikan tersebut untuk menjalankan sebuah program. Terdapat 5 metode penyusunan anggaran dari atas ke bawah:

a) perusahaan mengunakan sejumlah uang yang ada untuk kegiatan operasional dan produksi tanpa mempertimbangkan efek pengeluaran tersebut.

b) Metode pembagian semena-mena (Arbitrary allocation method) merupakan proses pendistribusian anggaran yang tidak lebih baik dari metode sebelumnya Metode ini tidak berdasar pada teori, tidak memiliki tujuan yang jelas, dan tidak membuat konsep pendistribusian anggaran dengan baik.

c) Metode persentase penjualan (Percentage of sales) menggambarkan efek yang terjadi antara kegiatan iklan dan promosi yang dilakukan dengan persentase peningkatan penjualan di lapangan. Metode ini mendasarkan pada dua hal, yaitu persentase penjualan dan sejumlah pengembalian yang diterima aktivitas periklanan dan promosi yang dilakukan.

d) Melihat pesaing (Competitive parity) karena sebenarnya tidak ada perusahaan yang tidak mau tahu akan keadaan pesaingnya. Tiap perusahaan akan berusaha untuk melakukan promosi yang lebih baik dari para pesaingnya dengan tujuan untuk menguasai pangsa pasar.

e) Pengembalian investasi (Return of investment) merupakan pengembalian keuntungan yang diharapkan oleh perusahaan terkait dengan sejumlah uang yang telah dikeluarkan untuk iklan dan aktivitas promosi lainnya. Sesuai dengan arti katanya, investasi berarti penanaman modal dengan harapan akan adanya pengembalian modal suatu hari.

2) Dari bawah ke atas (Bottom-up)

Merupakan proses Penyusunan Anggaran berdasarkan tujuan yang telah ditetapkan sebelumnya dan anggaran ditentukan belakangan setelah tujuan selesai disusun. Proses penyusunan anggaran dari bawah ke atas merupakan komunikasi strategis antara tujuan dengan anggaran. Terdapat 3 metode dasar proses penyusunan anggaran dari bawah ke atas, yakni:

a) Metode tujuan dan tugas (Objective and task method) dengan menegaskan pada penentuan tujuan dan anggaran yang disusun secara beriringan. Terdapat 3 langkah yang ditempuh dalam langkah ini, yakni penentuan tujuan, penentuan strategi dan tugas yang harus dikerjakan dan perkiraan anggaran 
yang dibutuhkan untuk mencapai tugas dan strategi tersebut.

b) Metode pengembalian berkala (Payout planning) menggunakan prinsip investasi dimana pengembalian modal diterima setelah waktu tertentu. Selama tahun pertama, perusahaan akan mengalami rugi dikarenakan biaya promosi dan iklan masih melebihi keuntungan yang diterima dari hasil penjualan, pada tahun kedua, perusahaan akan mencapai titik impas (break even point) antara biaya promosi dengan keuntungan yang diterima. Setelah memasuki tahun ketiga, barulah perusahaan akan menerima keuntungan penjualan. Strategi ini hasilnya akan dirasakan dalam jangka panjang.

c) Metode penghitungan kuantitatif (Quantitative models) menggunakan sistem perhitungan statistik dengan mengolah data yang dimasukan dalam computer dengan teknis analisis regresi berganda (multiple regression analysis). Metode ini jarang digunakan karena kompleks dalam pemakaiannya.

\section{METODE PENELITIAN}

\section{a. Teknik Analisis}

Analisis data yang digunakan dalam penelitian ini adalah analisis deskriptif. Sugiyono (2010:147) menyatakan bahwa analisis deskriptif adalah statistik yang digunakan untuk menganalisis data dengan cara mendeskri psikan atau menggambarkan data yang telah terkumpul sebagaimana adanya tanpa bermaksud membuat kesimpulan yang berlaku untuk umum atau generalisasi. Rasio efektitifitas menggambarkan kemampuan pemerintah daerah dalam merealisasikan PAD yang direncanakan dibandingkan target yang ditetapkan berdasarkan potensi rill daerah. Kemampuan daerah dalam menjalankan tugas dikategorikan efektif apabila rasio yang dicapai minimal sebesar 1 (satu) atau 100 persen. Semakin tinggi rasio efektifitas menggambarkan kemampuan daerah yang semakin baik.

Tingkat efektifitas diukur dengan cara membandingkan realisasi anggaran pendapatan dengan total anggaran pendapatan (Mahsun : 2013)

$$
\text { Rasio efektifitas }=\frac{\text { realisasi }}{\text { anggaran }} \times 100 \%
$$

Keputusan Menteri Dalam Negeri No. 690.900-327 Tahun 1996, kriteria tingkat efektifitas pendapatan sebagai berikut:

1) Jika hasil perbandingan lebih dari $100 \%$, maka pendapatan dikatakan sangat efektif

2) Jika hasil pencapaian 100\%, maka pendapatan dikatakan efektif

3) Jika hasil pencapaian antara 90\%-99\%, maka pendapatan dikatakan cukup efektif

4) Jika hasil pencapaian 75\%-89\%, maka pendapatan dikatakan kurang efektif

5) Jika hasil pencapaian dibawah 75\%, maka pendapatan dikatakan tidak efektif.

Tingkat efisiensi diukur dengan cara membandingkan realisasi anggaran belanja dengan total anggaran belanja (Mahsun : 2013).

$$
\text { Rasio efisiensi }=\frac{\text { realisasi }}{\text { anggaran }} \times 100 \%
$$

Keputusan Menteri Dalam Negeri No. 690.900-327 Tahun 1996, kriteria tingkat efisiensi anggaran belanja sebagai berikut: 
1 Jika hasil perbandingan lebih dari $100 \%$, maka anggaran belanja dikatakan tidak efisien

2 Jika hasil pencapaian antara 90\%$100 \%$, maka anggaran belanja dikatakan kurang efisien

3 Jika hasil pencapaian anatara 80\%$90 \%$, maka anggaran belanja dikatakan cukup efisien

4 Jika hasil pencapaian antara 60\%-80\%, maka anggaran belanja dikatakan efisien

5 Jika hasil pencapaian dibawah 60\%, maka anggaran belanja dikatakan sangat efisien.

\section{HASIL DAN PEMBAHASAN}

\section{a. Analisis Statistik Deskriptif}

KUA dan PPAS yang telah disepakati bersama akan menjadi dasar bagi Pemerintah Daerah untuk menyusun, menyampaikan dan membahas RAPBD TA 2017 antara Pemerintah Daerah dengan DPRD sampai dengan tercapainya persetujuan bersama antara KDH dengan DPRD terhadap raperda tentang APBD, paling lambat tanggal 30 November 2016, sebagimana diatur dalam ketentuan Pasal
105 ayat (3c) Peraturan Menteri Dalam Negeri Nomor 13 Tahun 2006.

Tahapan dan jadwal penyusunan APBD sampai RKA adalah sebagai berikut:

1) Penyusunan RKPD (akhir bulan mei)

2) Penyampaian Rancangan KUA dan Rancangan PPAS oleh ketua TAPD kepada Kepala Daerah (minggu 1 bulan juni)

3) Penyampaian Rancangan KUA dan Rancangan PPAS oleh Kepala Daerah ke DPRD (pertengahan bulan juni)

4) Kesepakatan antara Kepala Daerah dan DPRD atas Rancangan KUA dan Rancangan PPAS (awal bulan juli)

5) Penerbitan Surat Edaran Kepala Daerah perihal Pedoman Penyusunan RKA-SKPD dan RKA PPKD (awal bulan agustus)

6) Penyusunan \& pembahasan RKA-SKPD \& RKA-PPKD serta penyusunan Ranperda APBD (awal bulan agustus s/d akhir bulan september )

Tabel 4.1 Rencana Kerja Anggaran Tahun Anggaran 2016 - 2017

\begin{tabular}{|l|l|c|c|}
\hline TAHUN & \multicolumn{1}{|c|}{ URAIAN } & RENCANA & ANGGARAN \\
\hline 2016 & Pendapatan & $\mathbf{6 . 8 5 1 . 5 7 1 . 7 7 7 . 5 5 0 , 0 0}$ & $\mathbf{7 . 3 6 3 . 5 0 0 . 2 2 9 . 7 0 3 , 0 0}$ \\
\hline & 1. Pendapatan asli daerah & $3.511 .644 .271 .550,00$ & $3.516 .797 .239 .983,00$ \\
\hline & 2. Pendapatan transfer & $3.328 .111 .729 .000,00$ & $3.834 .773 .537 .720,00$ \\
\hline & $\begin{array}{l}\text { 3. Lain-lain pendapatan } \\
\text { yang sah }\end{array}$ & $11.815 .777 .000,00$ & $11.929 .452 .000,00$ \\
\hline & Belanja & $\mathbf{5 . 1 0 1 . 5 8 1 . 9 2 9 . 7 5 4 , 7 7}$ & $\mathbf{5 . 8 7 1 . 1 1 6 . 8 2 8 . 0 9 1 , 1 5}$ \\
\hline & 1. Belanja operasi & $4.207 .954 .369 .665,87$ & $4.936 .645 .528 .265,12$ \\
\hline & 2. Belanja modal & $868.879 .018 .870,14$ & $931.888 .751 .523,74$ \\
\hline & 3. Belanja tidak terduga & $24.748 .541 .218,76$ & $2.582 .548 .302,29$ \\
\hline & $\begin{array}{l}\text { Pendapatan } \\
\text { 1. Pendapatan asli daerah }\end{array}$ & $\mathbf{8 . 9 0 1 . 9 2 8 . 7 7 5 . 3 6 5 , 0 0}$ & $\mathbf{9 . 2 9 2 . 9 5 8 . 2 7 2 . 5 0 1 , 0 0}$ \\
\hline & $\begin{array}{l}\text { 2. } \text { Pendapatan transfer } \\
\text { sah }\end{array}$ & $5.166 .208 .141 .000,00$ & $5.536 .834 .278 .020,00$ \\
\hline
\end{tabular}




\begin{tabular}{|l|l|c|c|}
\hline & Belanja & $\mathbf{7 . 6 7 5 . 8 4 6 . 4 7 7 . 0 2 8 , 2 2}$ & $\mathbf{7 . 7 5 1 . 1 4 7 . 8 5 6 . 0 8 7 , 9 6}$ \\
\hline & 1. Belanja operasi & $6.591 .338 .409 .800,57$ & $6.563 .287 .993 .710,22$ \\
\hline & 2. Belanja modal & $1.059 .508 .067 .227,65$ & $1.177 .859 .862 .377,74$ \\
\hline & 3. Belanja tidak terduga & $25.000 .000 .000,00$ & $10.000 .000 .000,00$ \\
\hline
\end{tabular}


Sumber: RKA Badan Pengelola Keuangan Daerah Sul-Sel 2016-2017

Pendapatan asli daerah pada tahun 2016 perencanaan yang dilakukan sebesar Rp. 3.511.644.271.550,00 dan mengalami kenaikan anggaran sebanyak 0,14\% sedangkan pada tahun 2017 pendapatan asli daerah perencanaan yang dilakukan sebesar Rp. 3.724.172.762.535,00 dan mengalami kenaikan anggaran sebanyak $0,51 \%$.

Pendapatan transfer pada tahun 2016 perencanaan yang dilakukan sebesar Rp. 3.328.111.729.000,00 dan mengalami kenaikan anggaran sebanyak 5,22\% sedangkan pada tahun 2017 pendapatan transfer perencanaan yang dilakukan sebesar Rp. 5.166.208.141.000,00 dan mengalami kenaikan anggaran sebanyak $7,17 \%$.

Lain-lain pendapatan yang sah pada tahun 2016 perencanaan yang dilakukan sebesar Rp. 11.815.777.000,00 dan mengalami kenaikan anggaran sebesar Rp. 0,96\% sedangkan pada tahun 2017 Lain-lain pendapatan yang sah perencanaan yang dilakukan sebesar Rp. 11.547.871.830,00 dan mengalami kenaikan anggaran sebanyak 0,66\%. Belanja operasi pada tahun 2016 perencanaan yang dilakukan sebesar Rp. 4.207.954.369.665,87 dan mengalami kenaikan anggaran sebanyak 5,23\% sedangkan pada tahun 2017 Belanja operasi perencanaan yang dilakukan sebesar Rp. 6.591.338.409.800,57 dan mengalami penurunan anggaran sebanyak $9,57 \%$.

Belanja modal pada tahun 2016 perencanaan yang dilakukan sebesar Rp. 868.879.018.870,14 dan mengalami kenaikan anggaran sebanyak. 7,25\% sedangkan pada tahun 2017 Belanja modal perencanaan yang dilakukan sebesar Rp. 1.059.508.067.227,65 dan mengalami penurunan anggaran sebanyak 1,17\%. Belanja tidak terduga pada tahun 2016 perencanaan yang dilakukan sebesar Rp. 24.748.541.218,76 dan mengalami penurunan anggaran sebanyak $0,43 \%$ sedangkan pada tahun 2017 Belanja tidak terduga perencanaan yang dilakukan sebesar Rp. 25.000.000.000,00 dan mengalami penurunan anggaran sebanyak $0,4 \%$. Keputusan Menteri Dalam Negeri No. 690.900-327 Tahun 1996, kriteria tingkat efektifitas pendapatan sebagai berikut:

1) Jika hasil perbandingan lebih dari $100 \%$, maka pendapatan dikatakan sangat efektif

2) Jika hasil pencapaian 100\%, maka pendapatan dikatakan efektif

3) Jika hasil pencapaian antara 90\%-99\%, maka pendapatan dikatakan cukup efektif

4) Jika hasil pencapaian 75\%-89\%, maka pendapatan dikatakan kurang efektif

5) Jika hasil pencapaian dibawah $75 \%$, maka pendapatan dikatakan tidak efektif.

Hasil dari rasio efektifitas Badan Pengelola keuangan daerah (BPKD) Tahun Anggaran 2016, Anggaran Pendapatan asli Daerah sebesar Rp. 3.516.797.239.983,00 dan Realisasi Pendapatan asli daerah sebesar Rp. 3.449.561.308.104,52 Selisih antara anggaran dan realisasi sebanyak. 98,08\% dengan demikian diperoleh rasio efektivitas sebanyak 98\% dikategorikan cukup efektif.

Anggaran pendapatan transfer sebesar Rp. 3.834.773.537.720,00 dan realisasi pendapatan transfer sebesar Rp. 3.704.816.673.661,00 Selisih antara 
anggaran dan realisasi sebanyak 96,61\% dengan demikian dieroleh rasio efektifitas sebanyak 96\% dikategorikan cukup efektif. Sedangkan anggaran Lain-lain pendapatan yang sah sebesar Rp. 11.929.452.000,00 dan realisasi Lain-lain pendapatan yang sah sebesar $\mathrm{Rp}$. 8.210.709.417,00 Selisih antara anggaran dan realisasi sebanyak 68,82\% dengan demikian dieroleh rasio efektifitas sebanyak 68\% dikategorikan tidak efektif.

Hasil dari rasio efektifitas Badan Pengelola keuangan daerah (BPKD) Tahun Anggaran 2017, Anggaran Pendapatan asli Daerah sebesar Rp. 3.743.344.520.531,00 dan Realisasi Pendapatan asli daerah sebesar Rp. 3.678.689.065.719,45 Selisih antara anggaran dan realisasi sebanyak 98,27\% dengan demikian diperoleh rasio efektivitas sebesar 98\% dikategorikan cukup efektif. Dan anggaran pendapatan transfer sebesar Rp. 5.536.834.278.020,00 dan realisasi pendapatan transfer sebesar Rp. 5.362.007.388.022,00 Selisih antara anggaran dan realisasi sebanyak 96,84\% dengan demikian dieroleh rasio efektifitas sebesar $96 \%$ dikategorikan cukup efektif. Sedangkan anggaran Lain-lain pendapatan yang sah sebesar Rp. 12.779.473.950,00 dan realisasi Lain-lain pendapatan yang sah sebesar Rp. 14.187.575.578,00 Selisih antara anggaran dan realisasi sebanyak 111,01\% dengan demikian dieroleh rasio efektifitas sebesar $110 \%$ dikategorikan sangat efektif.

Keputusan Menteri Dalam Negeri No. 690.900-327 Tahun 1996, kriteria tingkat efisiensi anggaran belanja sebagai berikut:

1) Jika hasil perbandingan lebih dari $100 \%$, maka anggaran belanja dikatakan tidak efisien
2) Jika hasil pencapaian antara 90\%$100 \%$, maka anggaran belanja dikatakan kurang efisien

3) Jika hasil pencapaian anatara 80\%90\%, maka anggaran belanja dikatakan cukup efisien

4) Jika hasil pencapaian antara 60\%-80\%, maka anggaran belanja dikatakan efisien

5) Jika hasil pencapaian dibawah $60 \%$, maka anggaran belanja dikatakan sangat efisien.

Rasio Efisiensi $=\frac{\text { realisasi }}{\text { anggaran }} \times 100 \%$

Tahun 2016

$=\frac{5.522 .839 .080 .544,57}{5.871 .116 .828 .091,15} \times 100 \%$

$=94 \%$

Tahun 2017

$=\frac{7.364 .308 .138 .423,48}{7.751 \cdot 147.856 .087,96} \times 100 \%$

$=95 \%$

Hasil dari rasio efisiensi Badan Pengelola keuangan daerah (BPKD) Tahun Anggaran 2016, Anggaran belanja operasi sebesar Rp. 4.936.645.528.265,12 dan Realisasi belanja operasi sebesar Rp. 4.665.776.837.576,02 Selisih antara anggaran dan realisasi sebanyak. $94,51 \% \%$ dengan demikian diperoleh rasio efisiensi sebanyak $94 \%$ dikategorikan kurang efisien. Dan anggaran belanja modal sebesar Rp. 931.888.751.523,74 dan realisasi belanja modal sebesar Rp. 857.062.242.968,55 Selisih antara anggaran dan realisasi sebanyak 91,97\% dengan demikian dieroleh rasio efisiensi sebanyak 91\% dikategorikan kurang efisien. Sedangkan anggaran belanja tidak terduga sebesar Rp. 2.582.548.302,29 dan anggaran tersebut tidak terealisasi. 
Hasil dari rasio efisiensi Badan Pengelola keuangan daerah (BPKD) Tahun Anggaran 2017, Anggaran belanja operasi sebesar Rp. 6.563.287.993.710,22 dan Realisasi belanja operasi sebesar Rp. 6.313.089.042.752,68 Selisih antara anggaran dan realisasi sebanyak. 96,18\%\% dengan demikian diperoleh rasio efisiensi sebanyak 96\% dikategorikan kurang efisien. Dan anggaran belanja modal sebesar Rp. 1.177.859.862.377,74 dan realisasi belanja modal sebesar Rp. 1.051.187.330.670,80 Selisih antara anggaran dan realisasi sebanyak 89,24\% dengan demikian dieroleh rasio efisiensi sebanyak 89\% dikategorikan cukup efisien. Sedangkan anggaran belanja tidak terduga sebesar Rp. 10.000.000.000,00 dan realisasi belanja tidak terduga sebesar Rp. 31.765.000,00 Selisih antara anggaran dan realisasi sebanyak $0,31 \%$ dengan demikian dieroleh rasio efisiensi sebanyak $31 \%$ dikategorikan sangat efisien.

\section{Gambar 4.3 Rasio Efisiensi Anggaran Belanja Tahun 2016-2017}

\section{b. Analisis Dan Interpretasi (Pembahasan)}

Pendapatan pada tahun 2016 perencanaan yang dilakukan sebesar Rp. 6.851.571.777.550,00 dan mengalami kenaikan anggaran sebanyak $7,47 \%$ sedangkan pada tahun 2017 pendapatan perencanaan yang dilakukan sebesar $\mathrm{Rp}$. 8.901.928.775.365,00 dan mengalami kenaikan anggaran sebanyak 4,39\%. Belanja pada tahun 2016 perencanaan yang dilakukan sebesar Rp. 5.101.581.929.754,77 dan mengalami kenaikan anggaran sebanyak 5,08\% sedangkan pada tahun 2017 Belanja perencanaan yang dilakukan sebesar Rp. 7.675.846.477.028,22 dan mengalami kenaikan anggaran sebanyak 0,98\%.

Jika dilihat dari hasil analisis perencanaan anggaran pendapatan Badan Pengelola keuangan daerah (BPKD) Tahun Anggaran 2016 - 2017 mengalami kenaikan. Hal ini disebabkan karena selalu dilakukan peningkatan kapasitas SDM aparatur dan pemberdayaan SDM secara tepat dan kondusif dan dilakukan penertiban atau pemeriksaan dokumen pembayaran pajak secara optimal. Sedangkan hasil analisis perencanaan anggaran belanja Badan Pengelola keuangan daerah (BPKD) Tahun Anggaran 2016 - 2017 mengalami kenaikan. hal ini disebabkan karena belanja pelaksanaan pennggunaaan anggaran pemerintah itu tiap tahunnya selalu mengalami peningkatan contohnya peningkatan pelayanan Pendidikan dan kesehatan, serta peningkatan penyediaan fasilitas sosial dan umum.

Hasil dari rasio efektivitas Badan Pengelola keuangan daerah (BPKD) Tahun Anggaran 2016, Anggaran Pendapatan sebesar Rp. 7.363.500.229.703,00 dan Realisasi Pendapatan sebesar Rp. 7.162.588.691.182,52 Selisih antara anggaran dan realisasi sebanyak. 97,27\% dengan demikian diperoleh rasio efektivitas sebanyak 97\% dikategorikan cukup efektif. Karena sudah sesuai 
dengan keputusan Menteri Dalam Negeri No. 690.900-327 Tahun 1996 dengan rasio efektifitas hasil pencapaian antara 90\%-99\%, sedangkan tahun 2017 Anggaran Pendapatan sebesar Rp. 9.292.958.272.501,00 dan Realisasi Pendapatan sebesar Rp. 9.054.884.029.319,45 Selisih antara anggaran dan realisasi sebanyak. 97,43\% dengan demikian diperoleh rasio efektivitas sebanyak 97\% dikategorikan cukup efektif. Karena sudah sesuai dengan keputusan Menteri Dalam Negeri No. 690.900-327 Tahun 1996 dengan rasio efektifitas hasil pencapaian antara 90\%-99\%.

Hasil dari rasio efisiensi Badan Pengelola keuangan daerah (BPKD) Tahun Anggaran 2016, Anggaran belanja sebesar Rp. 5.871.116.828.091,15 dan Realisasi belanja sebesar Rp. 5.522.839.080.544,57 Selisih antara anggaran dan realisasi sebanyak. 94.06\% dengan demikian diperoleh rasio efisiensi sebanyak 94\% dikategorikan kurang efisien. Karena sudah sesuai dengan keputusan Menteri Dalam Negeri No. 690.900-327 Tahun 1996 dengan rasio efisiensi hasil pencapaian antara 90\%100\%, sedangkan tahun 2017 Anggaran belanja sebesar Rp. 7.751.147.856.087,96 dan Realisasi Pendapatan sebesar Rp. 7.364.308.138.423,48 Selisih antara anggaran dan realisasi sebanyak. 95,00\% dengan demikian diperoleh rasio efisiensi sebanyak 95\% dikategorikan kurang efisien. Karena sudah sesuai dengan keputusan Menteri Dalam Negeri No. 690.900-327 Tahun 1996 dengan rasio efisiensi hasil pencapaian antara 90\%$100 \%$.

Jika dilihat dari hasil efektifitas anggaran pendapatan Badan Pengelola keuangan daerah (BPKD) Tahun Anggaran 2016 - 2017 dikategorikan cukup efektif. sedangkan hasil efisiensi anggaran belanja Badan Pengelola keuangan daerah (BPKD) Tahun Anggaran 2016 - 2017 dikategorikan kurang efisien dikarenakan pengeluaran lebih besar daripada pendapatannya. Meskipun ada anggaran yang tidak terealisasi pada tahun 2016 yang disebabkan karena tidak adanya kegiatan tidak biasa atau tidak diharapkan berulang seperti penanggulangan bencana alam dan bencana sosial yang tidak diperkirakan sebelumnya, karena anggaran tidak terduga ini digunakan apabila ada keadaan darurat dan keperluan mendesak. Untuk anggaran yang tidak terealisasi akan dimasukkan ke Sisah Lebih Pembiayaan Anggaran (SILPA) dan dianggarkan ke tahun berikutnya.

\section{PENUTUP}

\section{a. Simpulan}

1) Perencanaan anggaran pendapatan dan belanja badan pengelola keuangan daerah rata rata mengalami peningkatan tahun anggaran 2016 2017, ini menunjukkan bahwa kantor BPKD berhasil menyusun dan merencanakan anggarannya dengan baik sampai tahap terealisasi.

2) Efektivitas Badan pengelola keuangan daerah Tahun Anggaran 2016 sampai dengan Tahun 2017 dilihat dari perhitungan rata-rata Rasio Efektivitasnya diperoleh antara 90\%$100 \%$ termasuk dalam Kriteria cukup Efektif. Hal ini berarti Pemerintah Badan pengelola keuangan daerah Sul - sel dikatakan berhasil Merealisasikan Pendapatan dengan Anggaran Pendapatannya. Efisiensi badan pengelola keuangan daerah sul - sel Tahun Anggaran 2016 sampai dengan Tahun 2017. Dilihat dari perhitungan 
rata-rata Rasio Efisiensinya diperoleh antara 90\%-100\%, termasuk dalam Kriteria Kurang Efisien. Yang dikarenakan pengeluarannya lebih besar daripada pendapatannya. Hal ini berarti Pemerintah Badan pengelola keuangan daerah Sul - sel dikatakan Kurang berhasil dalam Merealisasikan Belanja dengan Anggaran Belanjanya.

\section{b. Saran}

1) Dalam penyusunan RKA-SKPD harus memperhatikan jenis, objek dan rincian objek belanja yang akan dibutuhkan dalam suatu kegiatan sehingga realisasinya dapat mencapai hasil yang diingankan.

2) Setiap bulan atau paling lama 3 bulan dilakukan evaluasi program atau kegiatan apa saja yang belum dilaksanakan sesuai dengan anggaran kas sehingga dapat mencapai realisasi sesuai target.

\section{DAFTAR PUSTAKA}

Adisaputro, Gunawan. 2014. Anggaran Perusahaan. Buku I. BPFE Universitas Gajah Mada. Yogyakarta

Anggarini, Y dan puranto, B.H. 2016. anggaran berbasis kinerja penyusunan $A P B D$ secara khomprenshif. UPP STIM YKPN. Yogyakarta

Bhisma, M.et.al. 2013. perencanaan dan penganggaran untuk investasi kesehatan ditingkat kabupaten dan kota. gadja mada press university. Yogyakarta

Basariyah siti. 2017. analisis efektivitas dan efisiensi pelaksanaan anggaran belanja pada badan pemberdayaan masyarakat dan pemerintahan desa (BPMPD) daerah propinsi sulawesi tengah. e Jurnal Katalogis, Volume 5
Nomor 6, Juni 2017 hlm 63-74. ISSN: 2302-2019

Basri Ramlah. 2013. analisis penyusunan anggaran dan laporan realisasi anggaran pada bpm-pd provinsi sulawesi utara. Jurnal EMBA. Vol.1 No.4 Desember 2013, Hal. 202-212. ISSN 2303-1174

Dien A. N. J.dkk .2015. analisis laporan realisasi anggaran untuk menilai kinerja keuangan pada kantor dinas pendapatan daerah kota bitung. Jurnal EMBA. Vol.3 No.1 Maret 2015, Hal. 534-541. ISSN 23031174.

Gitosudarmo, Indriyo. 2014. manajemen pemasaran. edisi ke 2. cetakan ke 3. BPFE. Yogyakarta

Honga A. F. dan ventje I. 2014. analisis realisasi anggaran pendapatan dan belanja daerah pemerintah kota bitung. Jurnal EMBA. Vol.2 No.4 Desember 2014, Hal. 278-288. ISSN 2303-1174

Halim Abdul, Muhamad Iqbal. 2014. Pengelolaan Keuangan Negara. Penerbit Bulak Sumur. NPP STIM YKPN

Jauhari (2017) pengaruh perencanaan anggaran dan pelaksanaan anggaran terhadap serapan anggaran satuan kerja wilayah pembayaran kppn bandung $i$ dan kppn bandung ii. Artikel jurnal. Bandung: Pascasarjana Universitass Pasundang Bandung

Korompot R. dan Agus T. P. 2015. analisis penyusunan anggaran pada dinas pendapatan pengelolaan keuangan dan aset daerah kota kotamobagu tahun anggaran 2014. Jurnal EMBA. Vol.3 No.1 Maret 2015, Hal.841848. ISSN 2303-1174 
Mahsun, 2013. Metode penelitian Bahasa: tahapan, strategi, dan tekniknya. Raja grafindo persada. Jakarta

Munandar, M. 2014. Budgeting Perencanaan Kerja Pengkoordinasian Kerja Pengawasan Kerja. BPFE. Yogyakarta

Mulyadi, 2013. Akuntansi Manajemen .Edisi 3. Salemba Empat. Jakarta

Nafarin, M. 2013. Penganggaran Perusahaan. Salemba Empat. Jakarta

Nordiawan, Deddi, dkk. 2013. Akuntansi Pemerintahan, Salemba Empat, Jakarta

Nugroho, R. dan Randy R. Wrihatnolo, 2014, manajemen perencanaan pembangunan, PT. elex media kompulindo gramedia.

Pangkey M. Dan Sherly P. 2015. Analisis Efektivitas Dan Efisiensi Anggaran Belanja Pada Dinas Kebudayaan Dan Pariwsata Provinsi Sulawesi Utara. Jurnal EMBA. Vol.3 No.4 Desember 2015, Hal. 33-43. ISSN 2303-1174

Putra M. I. 2017. proses penyusunan anggaran pada dinas pendidikan pemuda dan olahraga kabupaten sleman Yogyakarta. Jurnal Riset Manajemen dan Bisnis (JRMB) Fakultas Ekonomi UNIAT Vol. 2, S1, September 2017: 271 - 280 P-ISSN 2527-7502 E-ISSN 2581-2165

Palilingan A. F. dkk. 2015. analisis kinerja belanja dalam laporan realisasi anggaran (Ira) pada dinas pendapatan kota manado. Jurnal EMBA. Vol.3 No.1 Maret 2015, Hal. 17-25. ISSN 2303-1174

Paramedy. 2011. analisis penyusunan dan penetapan anggaran APBD dinas kesehatan kabupaten nunukan tahun 2011. tesis diterbitkan UNHAS. makassar

Permendagri No. 56 Tahun 2007 Tentang Anggaran Pendapatan Dan Belanja Daerah

Peraturan pemerintah no. 71 tahun 2016 tentang standar akuntansi pemerintah

Robert, A. dan Govindarajan,Vijay. 2013. Sistem Pengendalian Manajemen. Salemba Empat. Jakarta.

Rukayah dkk. 2017. analisis laporan realisasi anggaran dengan menggunakan rasio efektivitas dan rasio efisiensi pada kantor badan perijinan terpadu dan penanaman modal kabupaten serang. Jurnal Akuntansi. Vol 4 No. 2 Juli 2017. pISSN 2339-2436. e-ISSN 2549-5968

Sugiyono. 2010. Metode Penelitian Kuantitatif, Kualitatif dan $R \& D$. Alfabeta. Bandung

Sugiyono. 2013.Cara Mudah Menyusun Skripsi, Tesis dan Disertasi. Alfabeta. Bandung

Syafri, Sofyan, Harahap. 2015. Budgeting Perencanaan Lengkap. PT. Gravindo Persada. Jakarta

Tanjung, A. H. 2013. penatausahaan dan akuntansi keuangan daerah. Edisi 3. salemba empat. Jakarta.

Wibawa Samodra. 2014. mengelola negara, pedoman untuk bupati, gubernur dan presiden. gaya media. Yogyakarta.

Yani, Ahmad, S.H., M.M., AK. 2013. hubungan keuangan antara pemerintah pusat dan daerah di Indonesia, edisi revisi, cetakan ke 5. PT. Gravindo Persada. Jakarta 
Profitability: Jurnal Ilmu Manajemen p-ISSN: 2714-6332-e-ISSN: 2714-6324

Vol.4 Nomor 1 Februari 2020 